\title{
Characterization and Potential Evaluation of Residues from the Sugarcane Industry of Rio Grande do Sul in Biorefinery Processes
}

\author{
Grazielle Machado ${ }^{*}$, Fernando Santos ${ }^{2}$, Douglas Faria1, Taiane Nunes de Queiroz ${ }^{2}$, \\ Flávia Zinani ${ }^{3}$, José Humberto de Queiroz ${ }^{4}$, Fernando Gomes ${ }^{5}$ \\ ${ }^{1}$ Instituto do Petróleo e dos Recursos Naturais, Pontifícia Universidade Católica do Rio Grande do Sul, Porto Alegre, Brazil \\ ${ }^{2}$ Centro de Estudos em Biorrefinaria, Universidade Estadual do Rio Grande do Sul, Porto Alegre, Brazil \\ ${ }^{3}$ Escola Politécnica, Universidade do Vale do Rio dos Sinos, São Leopoldo, Brazil \\ ${ }^{4}$ Departamento de Bioquímica e Biologia Molecular, Universidade Federal de Viçosa, Viçosa, Brazil \\ ${ }^{5}$ Instituto de Florestas, Universidade Federal Rural do Rio de Janeiro, Seropédica, Brazil \\ Email: ^graziellediasmachado@gmail.com
}

How to cite this paper: Machado, G. Santos, F., Faria, D., de Queiroz, T.N., Zinani, F., de Queiroz, J.H. and Gomes, F. (2018) Characterization and Potential Evaluation of Residues from the Sugarcane Industry of Rio Grande do Sul in Biorefinery Processes. Natural Resources, 9, 175-187. https://doi.org/10.4236/nr.2018.95011

Received: March 28, 2018

Accepted: May 8, 2018

Published: May 11, 2018

Copyright $\odot 2018$ by authors and Scientific Research Publishing Inc. This work is licensed under the Creative Commons Attribution International License (CC BY 4.0).

http://creativecommons.org/licenses/by/4.0/

\section{(c) (i) Open Access}

\begin{abstract}
Brazil is the world largest producer of sugarcane (Saccharum officinarum) leading to a great generation of residues such as bagasse and straw, which represent two thirds of sugarcane energetic potential. Regarding these residues energetic potential, it is interesting to study their application in biorefinery processes. Thus, this work aimed at performing a chemical characterization of sugarcane straw and bagasse from RB867515 cultivar grown in Rio Grande do Sul-Brazil aiming at their use as feedstock in biorefinery processes. The obtained results were compared to data from other states and it was possible to conclude that edaphoclimatic conditions of Rio Grande do Sul have little influence in sugarcane residues chemical composition. Sugarcane bagasse presents larger potential for energetic use because of its volatiles content $(74.82 \%)$ slightly higher than straw $(68.90 \%)$, besides its high lignin content $(21.85 \%)$ and higher calorific value $(18.70 \mathrm{MJ} / \mathrm{kg})$. Both sugarcane residues produced in Rio Grande do Sul have potential use as substrate in the obtainment of high value-added products from their cellulosic fractions $(41.30 \%$ and $37.25 \%$, respectively). The evaluation of energetic and chemical potential of sugarcane bagasse and straw produced in Rio Grande do Sul leads to the conclusion that these materials have high potential for use as feedstock in biorefineries.
\end{abstract}

\section{Keywords}

Saccharum officinarum, Straw, Bagasse, Biomass 


\section{Introduction}

The demand of materials from renewable resources which can replace oil based chemicals and fuels is increasing lately because of the progressive depletion of natural resources, instability of oil prices and environmental impact caused by pollution [1] [2]. Several developing and developed countries are investing in the development of products renewable and sustainable, which do not cause harm to the environment, based mainly on lignocellulosic biomass [3] [4].

Among the bioproducts that can be obtained from biomass, bioethanol can be highlighted. During sugarcane processing, 12 tons of bagasse and 12 tons of straw are generated per hectare of sugarcane. It is possible to increase bioethanol production, as well as produce other high value added products, without increasing the cultivated sugarcane area, by using sugarcane residues in biorefinery processes. Bagasse and straw comprise two thirds of sugarcane energetic potential, so that the use of these residues as feedstock in biorefineries is a promising alternative to attend the growing world demand for sustainable products from a renewable resource [5].

Brazil is the world largest sugarcane producer with an estimated production of 658.7 million tons of sugarcane in the harvest 2015/16 [6]. Sugarcane production in Rio Grande do Sul represents a small fraction of the country production. One of the limitations of producing sugarcane in this state is the humid subtropical climate, once sugarcane develops better in tropical climates with lower chance of frost [7]. In order to overcome the cold weather and drought usual in the state, more resistant varieties of sugarcane have been studied, such as RB cultivars. These cultivars are suitable for ethanol production and when tested in Rio Grande do Sul achieved average to high agricultural productivity, regular conditions when exposed to cold stress, good plant health and fast growth [8].

Once lignocellulosic chemical composition varies significantly according to type of plant, type of tissue, growing conditions and plant age, in order to have an integral use of biomass, efficiently in a biorefinery, it is necessary to perform a characterization regarding chemical and energetic potential of the lignocellulosic biomass. Through characterization, it is possible to determine the potential of each type of biomass for production of different products, as well as the choice of the best type of pretreatment and conversion technique to obtain a feasible and lucrative process [9].

In this context, this work aimed to characterize and study the potential of sugarcane cultivar RB867515 residues, straw and bagasse, produced in Rio Grande do Sul, Brazil, to obtain high value added products through biorefinery processes.

\section{Material and Methods}

\subsection{Feedstock}

The raw materials used in the experiments were sugarcane cultivar RB867515 
residues, straw and bagasse, grown in Pelotas, a city in Rio Grande do Sul, Brazil, provided by Embrapa Clima Temperado.

\subsection{Sample Processing}

Samples were dried at room temperature for four days. After drying, samples were milled in a knife mill. Then, the samples were classified using a set of sieves, such that the fractions which passed through 40 mesh sieve but were retained in the 60 mesh sieve were used in the experiments.

\subsection{Immediate Chemical Analysis}

Immediate chemical analysis is used to determine moisture, ash, volatiles and fix carbon contents. Moisture content was obtained following TAPPI T264 om-88. Ash content was obtained following TAPPI T211om-88 [10]. Volatiles and fix carbon were determined following ABNT NBR 8112 standard [11]. Samples used in the moisture content determination were used in the volatiles determination. These samples were left in a muffle at $950^{\circ} \mathrm{C}$ for 7 minutes, 2 minutes in the front part and five minutes in the back part. After this process, samples were placed in a desiccator for cooling and finally weighing. Volatiles content was calculated using Equation (1). Fixed carbon is calculated using Equation (2), in which $M C$ corresponds to moisture content, $V$ to volatiles content and $A$ to ashes content.

$$
\text { Volatiles } \%=\frac{\text { initial sample mass-finalsample mass }}{\text { initial sample mass }} \times 100 \%
$$

Fix carbon $=100-(M C+V+A)$

\subsection{Elemental Analysis}

Elemental analysis was performed following Pregl-Dumas method, an automated calorimetric method, used to determine carbon, hydrogen, oxygen, nitrogen and sulfur in the samples. The elemental analysis equipment manual was followed. The samples were burned in an elemental analyzer TRUSPEC non-dispersive, Leco brand, equipped with an infrared detector. In this equipment, the samples were burned in oxygen atmosphere at the temperature of $950^{\circ} \mathrm{C}$. Sulfur analysis was performed in elemental analyzer Leco SC-632, equipped with an infrared detector. In this equipment, samples were burned in oxygen atmosphere at the temperature of $1350^{\circ} \mathrm{C}$. Oxygen determination was obtained by difference, as shown in the equation below [12]:

$$
\% \mathrm{O}=100-(\% \mathrm{C}+\% \mathrm{H}+\% \mathrm{~N}+\% \mathrm{~S}+\% \text { Ashes })
$$

\subsection{Calorific Value}

In order to estimate the energetic potential of the samples, their high calorific value was determined using a bomb calorimeter, Parr brand, type 6300, following the equipment manual. 


\subsection{Chemical Analysis}

Chemical analysis was performed in the samples to determine the contents of cellulose, hemicelluloses, lignin, extractives and ashes, this last one previously determined in the immediate chemical analysis.

Carbohydrates, cellulose and hemicelluloses, were determined by Saeman method, in which polysaccharides are hydrolyzed, and the sugar monomers formed are quantified using ionic exchange chromatography. Carbohydrates analyzed were glucans, xylans, galactans, mannans, arabinans, as well as acetyl and uronic groups were determined. The ionic exchange chromatographer used was IC-3000 Dionex with pulsed amperometric detector HPAE-PAD. Sugars were separated using a protection column Carbo-Pac PA1 and an analytic column connected in series. Sample peaks observed on the chromatogram were compared to standard peaks of the sugars analyzed and quantification was obtained by the analyte area on a calibration curve of each compound, following TAPPI 222om-88 standard.

Total extractives determination in the samples was based on TAPPI T204om-88 and TAPPI T264om-88, through extraction of volatiles compounds in biomass using ethanol: toluene (1:2), followed by ethanol $95 \%$ and hot water in this order of polarity.

Lignin content determination was adapted from TAPPI 222om-88 standard, in which Klason lignin, insoluble lignin content, is obtained [11]. Klason lignin filtrate was diluted and analyzed by ultraviolet absorption in the wavelength of $280 \mathrm{~nm}$ and $215 \mathrm{~nm}$. Soluble lignin amount in the filtrate was determined by the following equation [13]:

$$
\text { Soluble lignin content }=\frac{\left(4538 \times A_{215}\right)-A_{280}}{300 \times D W} \times 10
$$

in which:

$$
\begin{aligned}
& A_{215}=\text { Absorbance in the wavelength of } 215 \mathrm{~nm} ; \\
& A_{280}=\text { Absorbance in the wavelength of } 280 \mathrm{~nm} ; \\
& D W=\text { Dry weight of the sample used in Klason lignin determination. }
\end{aligned}
$$

\subsection{Thermogravimetric Analysis (TGA)}

Thermogravimetric analysis was performed using equipment model SDT Q600 TA Instrument in $90 \mu \mathrm{L}$ alumina crucibles. Samples were heated from $25^{\circ} \mathrm{C}$ to $800^{\circ} \mathrm{C}$, in $\mathrm{N}_{2}$ atmosphere, at a heating rate of $10^{\circ} \mathrm{C} / \mathrm{min}$, in which samples of nearly 5.0 to $6.0 \mathrm{mg}$ were used. Thermogravimetric curves were registered between $25^{\circ} \mathrm{C}$ and $800^{\circ} \mathrm{C}$.

\section{Results and Discussion}

\subsection{Immediate Chemical Analysis}

The average of the results obtained in the immediate chemical analysis of sugarcane straw and bagasse grown in Rio Grande do Sul are shown in Table 1 along 
Table 1. Immediate chemical composition of sugarcane straw and bagasse.

\begin{tabular}{ccccccc}
\hline Biomass & State & $\begin{array}{c}\text { Moisture } \\
(\%)\end{array}$ & Ashes (\%) & Volatiles (\%) & $\begin{array}{c}\text { Fix Carbon } \\
(\%)\end{array}$ & References \\
\hline Bagasse & RS & 8.58 & 3.56 & 74.82 & 13.05 & $\begin{array}{c}\text { Authors } \\
2016^{*}\end{array}$ \\
& GO & 18.38 & 3.38 & 84.54 & 12.08 & $* *[14]$ \\
& SP & 10.51 & 4.00 & 69.39 & 16.10 & $*[15]$ \\
Straw & RS & 12.19 & 3.86 & 68.90 & 15.05 & $\begin{array}{c}\text { Authors } \\
2016^{*}\end{array}$ \\
& SP & 10.25 & 7.00 & 66.40 & 16.35 & $*[15]$ \\
& MG & 3.12 & 9.17 & 87.6 & 3.22 & $* *[16]$ \\
\hline
\end{tabular}

a. ${ }^{\star}$ Results in wet basis. ${ }^{*}$ Results in dry basis. RS: Rio Grande do Sul; GO: Goiás; SP: São Paulo; MG: Minas Gerais.

with results obtained in other studies using the same types of biomass grown in other regions of Brazil.

The observed differences can be explained by transportation and storage conditions of the samples, which can cause differences in their moisture content. Concerning the observed differences when comparing the results of the current study with [14] and [16] studies, differences can be explained by the fact that in these studies results were expressed in dry basis, while in the current study results were expressed in wet basis.

Regarding ash content in sugarcane straw, the value obtained in the current study (3.86\%) is lower than the value obtained by [15] (7.00\%) and [16] (9.17\%). These differences in the ash content can be explained by the part of the sugarcane from which straw was collected, once straw collected near the soil presents ash content around $7 \%-8 \%$, while straw collected in the middle or green leaves of sugarcane present ash content around $2 \%-3 \%$ [2].

Immediate chemical analysis is one of the most important parameters to evaluate biomass energetic potential. It is desired moisture content to be the lowest possible in biomass, once higher the moisture, more energy is necessary to start the burning process, in other words, more energy is required to vaporize water and less energy is supplied to the endothermic reaction [17]. Ashes have a negative influence in the calorific value, so lower contents of ashes are desirable for energetic uses. Higher volatiles content is desired, because these compounds increase biomass energetic potential. Yet, fix carbon content is directly related to coal content formed at the end of combustion process. Higher fix carbon content has a positive influence in increasing biomass high calorific value [14] [18].

\subsection{Elemental Analysis}

The average of the results obtained in the elemental analysis of sugarcane straw and bagasse grown in Rio Grande do Sul are shown in Table 2 along with results obtained in other studies using the same types of biomass grown in other 
Table 2. Elemental composition of sugarcane straw and bagasse.

\begin{tabular}{lccccccc}
\hline Biomass & State & $\mathrm{C}(\%)$ & $\mathrm{H}(\%)$ & $\mathrm{N}(\%)$ & $\mathrm{S}(\%)$ & $\mathrm{O}(\%)$ & References \\
\hline Bagasse & RS & 43.35 & 6.25 & 0 & 0.05 & 45.79 & Authors 2016 \\
& MG & 46.4 & 5.9 & 0.7 & 0 & 43.4 & {$[19]$} \\
& GO & 45.57 & 5.57 & 0.305 & 0.04 & 45.135 & {$[14]$} \\
\multirow{5}{*}{ Straw } & RS & 40.90 & 6.30 & 0.60 & 0 & 48.34 & Authors 2016 \\
& SP & 41.6 & 5.8 & 0.45 & 0.08 & 40.04 & {$[20]$} \\
& MG & 45.0 & 5.8 & 0.7 & 0 & 42.9 & {$[19]$} \\
\hline
\end{tabular}

RS: Rio Grande do Sul; MG: Minas Gerais; GO: Goiás; SP: São Paulo.

regions of Brazil. It is important to highlight that the ash content used to calculate oxygen content was the one obtained through immediate chemical analysis.

The results obtained for elemental composition of both sugarcane straw and bagasse do not differ significantly from the elemental composition of the same residues produced in different states of Brazil, proving that edaphoclimatic conditions of Rio Grande do Sul have no significant influence in elemental composition of sugarcane straw and bagasse.

Determination of elemental composition is important since from biomass main components amount, it is possible to do stoichiometric calculations for several uses in thermochemical processes. In combustion and gasification, these values allow to calculate amount of $\mathrm{CO}_{2}$ and $\mathrm{H}_{2} \mathrm{O}$ produced in complete combustion; amount of air required for fuel gasification; amount of adsorbent required to remove sulfur from combustion gas; besides to estimate high and low calorific value [21].

\subsection{Calorific Value}

The average of the results obtained in the determination of high calorific value of sugarcane straw and bagasse grown in Rio Grande do Sul are shown in Table 3 along with results obtained in other studies using the same types of biomass grown in other regions of Brazil.

The results obtained allow concluding that the edaphoclimatic conditions of Rio Grande do Sul do not have significant influence in the high calorific value of sugarcane bagasse and straw, once the results obtained were similar to results found in other studies.

Calorific value is a parameter highly influenced by biomass chemical composition. Moisture and ash contents are the factors that mostly influence biomass calorific value, the higher these contents are, the lowest will be biomass high calorific value, while lignin and extractives when present in larger amounts reflect in higher biomass calorific value. Thus, it is observed that biomass energetic potential is directly influenced by its composition, showing the importance of evaluating biomass composition previously to its industrial use [25].

\subsection{Chemical Characterization}

Chemical characterization was performed to evaluate the use of sugarcane bagasse 
Table 3. High calorific value of sugarcane straw and bagasse.

\begin{tabular}{cccc}
\hline Biomass & State & High calorific value $(\mathrm{MJ} / \mathrm{kg})$ & References \\
\hline Straw & RS & 18.30 & Authors 2016 \\
& MG & 18.80 & {$[22]$} \\
SP & 19.20 & {$[22]$} \\
PR & 19.00 & {$[22]$} \\
MT & 18.80 & {$[22]$} \\
AL & 19.30 & {$[22]$} \\
Bagasse & 18.17 & Authors 2016 \\
& MG & 18.70 & {$[17]$} \\
& PR & 15.55 & {$[23]$} \\
& MG & 18.25 & {$[24]$} \\
\hline
\end{tabular}

RS: Rio Grande do Sul; MG: Minas Gerais; SP: São Paulo; PR: Paraná; MT: Mato Grosso; AL: Alagoas; MS: Mato Grosso do Sul.

and straw as feedstock in biorefinery processes. The averages of the results obtained in the chemical characterization, including contents of cellulose (C), hemicelluloses $(\mathrm{H})$, lignin $(\mathrm{L})$, total extractives (TE) and ashes (A), of sugarcane straw and bagasse grown in Rio Grande do Sul are shown in Table 4 along with results obtained in other studies using the same types of biomass grown in other regions of Brazil.

Cellulose content found for sugarcane straw cultivated in Rio Grande do Sul is below the amounts of cellulose found by [22] for sugarcane cultivated in other states. Yet, cellulose content found for sugarcane bagasse produced in Rio Grande do Sul is similar to cellulose contents found in bagasse produced in other states. Larger amounts of cellulose in lignocellulosic biomass favor biofuels production such as ethanol and 2,3-butanediol produced from fermentable sugars derived from polysaccharides present in biomass. Glucose obtained from cellulose can also be used as substrate for producing biopolymers, such as polyhydroxyalkanoates (PHA). Some enzymes as $\alpha$-amylases, cellulases, among other enzymes and some organic acids as itaconic, succinic and lactic acids can be produced using glucose from cellulose as substrate through fermentation. Larger amounts of cellulose favor the obtainment of bioproducts by fermentation, as long as pretreatment and hydrolysis processes are efficient, releasing glucose, which is used in the fermentation processes [29].

Hemicelluloses content found for sugarcane straw cultivated in Rio Grande do Sul is below the amounts of cellulose found by [22] for sugarcane cultivated in other states. Yet, hemicelluloses content found for sugarcane bagasse produced in Rio Grande do Sul is similar to cellulose contents found in bagasse produced in other states. In the biorefinery context, among products that can be obtained from pentoses present in hemicelluloses, there is furfural, which is a promising alternative, since it is a versatile compound that can be used in the synthesis of 
Table 4. Chemical characterization of sugarcane straw and bagasse.

\begin{tabular}{ccccccccc}
\hline Biomass & State & $\mathrm{C}^{*}(\%)$ & $\mathrm{H}^{*}(\%)$ & $\mathrm{L}^{*}(\%)$ & $\mathrm{A}^{*}(\%)$ & $\mathrm{TE}^{*}(\%)$ & Total (\%) & References \\
\hline Straw & RS & 37.25 & 19.90 & 21.65 & 3.86 & 13.85 & 96.51 & Authors 2016 \\
& MG & 45.30 & 31.51 & 16.70 & 5.90 & 16.10 & 99.41 & {$[22]$} \\
& SP & 44.44 & 30.70 & 19.80 & 3.90 & 16.70 & 98.84 & {$[22]$} \\
& PR & 44.98 & 30.92 & 18.90 & 4.80 & 16.80 & 99.60 & {$[22]$} \\
& MT & 43.57 & 30.53 & 19.40 & 5.30 & 16.70 & 98.80 & {$[22]$} \\
& AL & 43.02 & 31.85 & 20.20 & 4.40 & 14.10 & 99.47 & {$[22]$} \\
Bagasse & RS & 41.30 & 28.05 & 21.85 & 3.56 & 6.35 & 101.11 & Authors 2016 \\
& PE & 41.12 & 27.76 & 21.03 & 4.08 & 5.16 & 99.16 & {$[26]$} \\
& SP & 40.5 & 24.5 & 26.4 & 1.6 & 0.6 & 93.6 & {$[27]$} \\
& PR & 41.8 & 22.9 & 30.4 & 3.1 & 6.7 & 104.9 & {$[28]$} \\
\hline
\end{tabular}

${ }^{\star}$ C: cellulose, H: hemicelluloses, L: lignin, A: ashes, TE: total extractives. RS: Rio Grande do Sul; MG: Minas Gerais; SP: São Paulo; PR: Paraná; MT: Mato Grosso; AL: Alagoas; PE: Pernambuco.

several important chemicals, as furan and furfuryl alcohol. Also, it is largely employed in several industrial applications in oil refineries, plastics and pharmaceuticals production, and agrochemical industry [30]. Xylose, present in hemicelluloses, can also be used in the production of xylitol, a sweetening agent used in several applications, which can be prepared through xylose hydrogenation [31]. Some fungi, as the basidiomycete Trametes hirsuta, have lignolytic enzymes (laccases), so that they are capable of producing ethanol from lignocellulosic residues. This basidiomycete is capable of converting not only glucose, but also xylose in ethanol, as well as it is capable of degrading lignocellulosic residues, dispensing the need to perform enzymatic hydrolysis [32]. Comparing the results obtained for sugarcane straw and bagasse produced in Rio Grande do Sul, since sugarcane bagasse presents higher amount of hemicelluloses, it is suitable for production of high value added products derived from hemicelluloses, such as xylitol, furfural and their derivatives.

Lignin contents found for sugarcane bagasse and straw cultivated in Rio Grande do Sul are within the range of lignin contents found for these residues cultivated in other states. When the objective is to explore biomass energetic potential, high amounts of lignin are desired, since lignin contains a larger amount of oxygen when compared to cellulose and hemicelluloses, which reflects in higher calorific value [25]. Yet, when the objective is to produce high value added through fermentation of monosaccharides, obtained from cellulose and hemicelluloses hydrolysis, smaller amounts of lignin are desirable, since lignin is one of the main fermentation inhibitors [33].

Ashes and extractives are minor compounds in lignocellulosic biomass. The values found for both sugarcane straw and bagasse are within the range of values found for ash content in sucroenergetic residues produced in other regions of Brazil. Regarding extractives content, although the result obtained for sugarcane straw produced in Rio Grande do Sul (13.85\%) is a little lower than the values 
found for straw produced in other states, it is still close value. Yet, the extractives content found for sugarcane bagasse produced in Rio Grande do Sul (6.35\%) is close to the result found by [26] (5.16\%) [28] (6.7\%), but differs from the result obtained by [27] $(0.6 \%)$. These differences may be explained by different methodologies employed to determine extractives content. It is important to highlight that higher content of extractives and lower content of ashes are interesting for biomass energetic uses.

\subsection{Thermogravimetric Analysis (TGA)}

Thermogravimetric analysis allows to follow mass losses in the sample being analyzes as a function of temperature. Through thermogravimetric curves, it is possible to relate different regions of mass losses as a function of temperature with different biomass components. Thermogravimetric curves obtained for sugarcane bagasse and straw samples are shown in Figure 1 and Figure 2, respectively.

[15] studied thermal decomposition of different types of lignocellulosic biomass including sugarcane bagasse and evidenced the presence of three zones of mass loss in the thermogravimetric analysis, one around $100^{\circ} \mathrm{C}$ attributed to water loss, and other two regions, one around $200^{\circ} \mathrm{C}-350^{\circ} \mathrm{C}$ and the other around $350^{\circ} \mathrm{C}-500^{\circ} \mathrm{C}$ due to organic matter degradation. This behavior was also observed in the sugarcane straw and bagasse samples in the current study.

[34] evidenced that hemicelluloses decomposition occurs predominantly under $230^{\circ} \mathrm{C}$ due to instability of acetyl groups. Cellulose degradation occurs

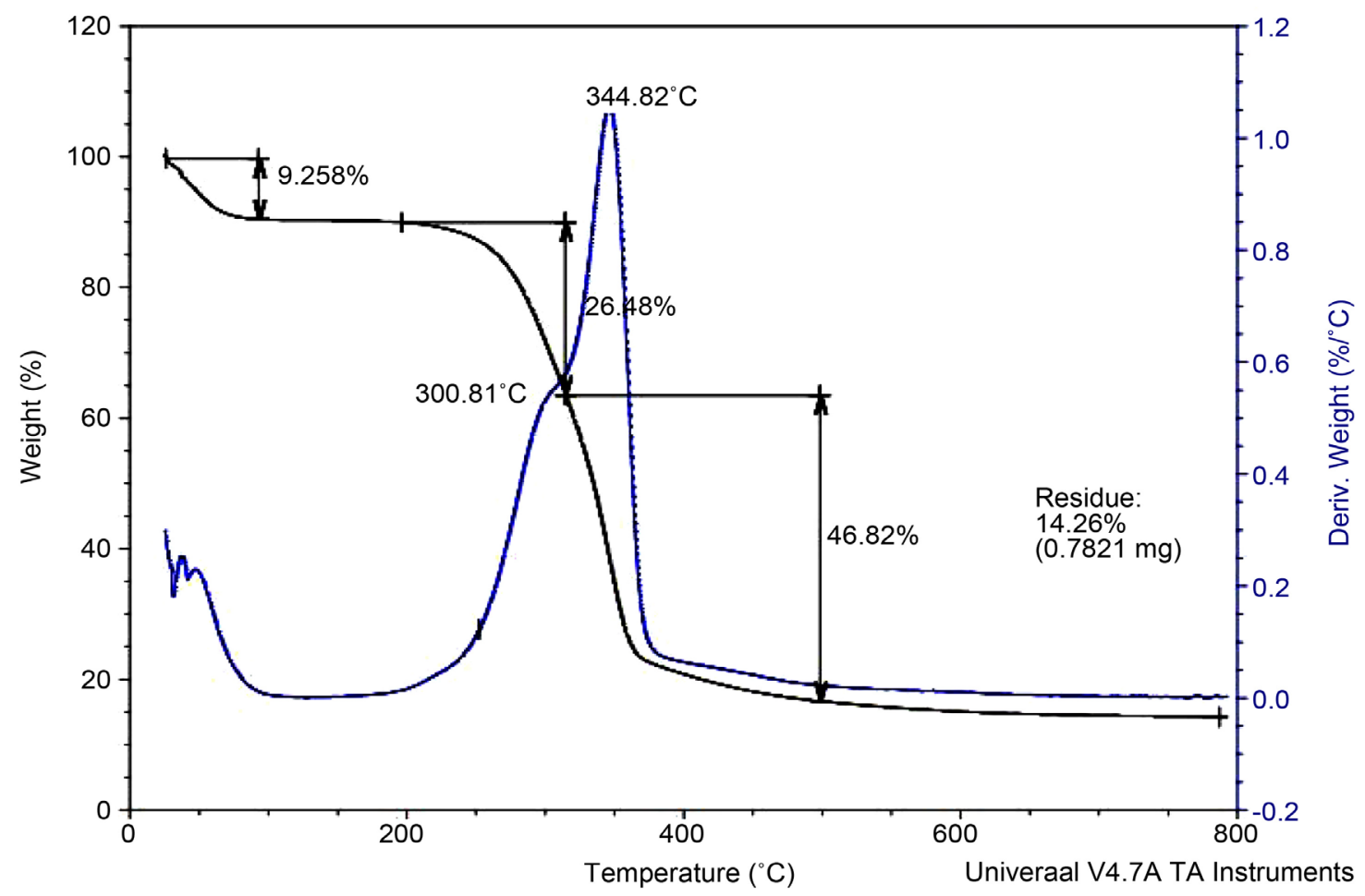

Figure 1. Thermogravimetric curve of sugarcane bagasse produced in Rio Grande do Sul. 


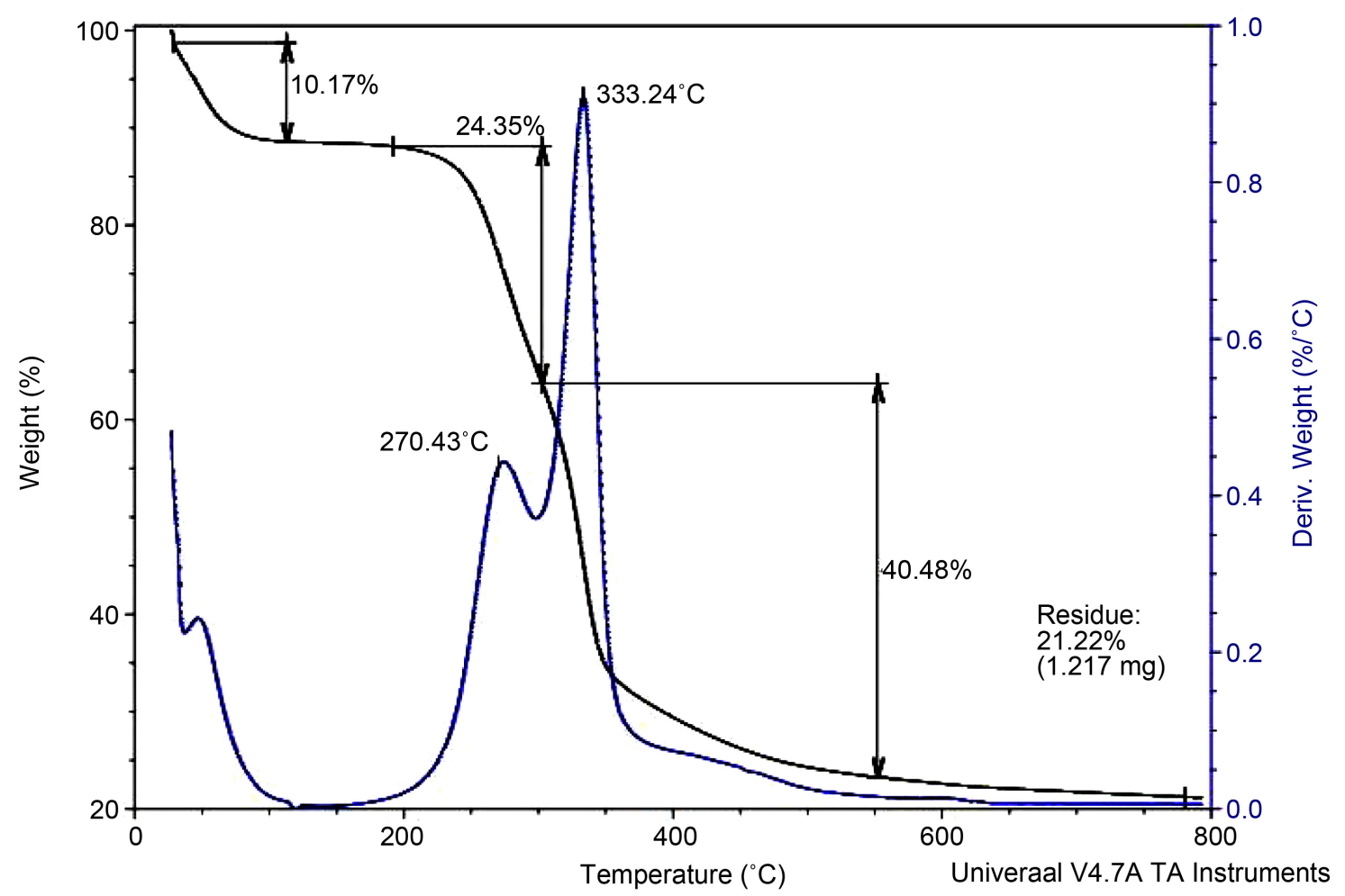

Figure 2. Thermogravimetric curve of sugarcane straw produced in Rio Grande do Sul.

normally in the range of $275^{\circ} \mathrm{C}-500^{\circ} \mathrm{C}$. Yet, lignin decomposition happens through an extensive temperature range, wherein under $500^{\circ} \mathrm{C}$ about $40 \%$ of lignin is decomposed, while the rest is degraded in higher temperatures [35] [36]. Thus, the second zone of mass loss in each thermogravimetric curve is mainly related to thermal degradation of hemicelluloses along with smaller amounts of cellulose and lignin, while the third zone in each curve is predominantly related to thermal degradation of cellulose along with smaller amounts of hemicelluloses and lignin. The solid residue remaining at the end of the process consists of fix carbon and ashes [15].

\section{Conclusions}

Overall, from the results obtained in the current study, it is possible to conclude that edaphoclimatic conditions of Rio Grande do Sul have no significant influence and chemical composition and energetic potential of sugarcane straw and bagasse when compared to other regions in Brazil. Bagasse presents higher potential for energetic uses compared to straw due to slightly higher volatiles content, along with high lignin content and high calorific value. Both bagasse and straw have potential to be used as substrates to obtain high value added products from their cellulosic fractions, such as organic acids, biofuels and biopolymers. Bagasse presents higher potential of use as substrate for production of high value added products derived from hemicellulose, such as xylitol and furfural, because of its higher hemicelluloses content. 
Finally, sugarcane straw and bagasse produced in Rio Grande do Sul present huge potential of use in biorefinery processes. However, more studies and improvement of technologies employed are needed for a better use of chemical and energetic fractions present in sugarcane to achieve higher efficiencies and yields in biorefinery processes.

\section{Acknowledgements}

Authors wish to acknowledge Embrapa Clima Temperado for providing the samples; Instituto do Petróleo e dos Recursos Naturais (PUCRS) and Laboratório de Papel e Celulose (UFV) for enabling analysis accomplishment; and FAPERGS for the scholarship.

\section{References}

[1] Huang, C.F., Jiang, Y.F., Guo, G.L. and Hwang, W.S. (2013) Method of 2,3-Butanediol Production from Glycerol and Acid-Pretreated Rice Straw Hydrolysate by Newly Isolated Strains: Pre-Evaluation as an Integrated Biorefinery Process. Bioresource Technology, 135, 446-453. https://doi.org/10.1016/j.biortech.2012.10.141

[2] Santos, F., Colodette, J. and Queiroz, J.H. (2013) Bioenergia e Biorrefinaria-Cana-de-Açúcar e Espécies Florestais (Bioenergy and Biorefinery-Sugarcane and Forestry Species). Editora UFV, Viçosa.

[3] Singh, R., Srivastava, V., Chaudhary, K., Gupta, P., Prakash, A., Balagurumurthy, B. and Bhaskar, T. (2015) Conversion of Rice Straw to Monomeric Phenols under Supercritical Methanol and Ethanol. Bioresource Technology, 188, 280-286. https://doi.org/10.1016/j.biortech.2015.01.001

[4] Kim, I., Lee, B., Park, J.Y., Choi, S.A. and Han, J.I. (2014) Effect of Nitric Acid on Pretreatment and Fermentation for Enhancing Ethanol Production of Rice Straw. Carbohydrate Polymers, 99, 563-567. https://doi.org/10.1016/j.carbpol.2013.08.092

[5] Santos, F.A., Queiroz, J.H., Colodette, J.L., Manfredi, M., Queiroz, M.E.L.R., Caldas, C.S. and Soares, F.E.F. (2014) Otimização do pré-tratamento hidrotérmico da palha de cana-de-açúcar visando à Produção de etanol celulósico. (Optimization of Hydrothermal Pretreatment in Sugarcane Straw Aiming Second Generation Ethanol Production) Química Nova, 37, 56-62. https://doi.org/10.1590/S0100-40422014000100011

[6] Conab. Companhia Nacional do Abastecimento. (2015) Acompanhamento safra brasileira cana (Following Brazilian Sugarcane Harvest). Vol. 2, Brasília, 1-65.

[7] Verissimo, M.A.A. (2012) Desempenho agronômico de genótipos de cana-de-açúcar no estado do Rio Grande do Sul (Agricultural Development of Sugarcane Genotypes in the State of Rio Grande do Sul). M.S. Thesis, Universidade Federal de Pelotas, Pelotas.

[8] Revista Rural. (2013) Cana gaúcha-Um produto “tri-legal”. (“Gaucha” Sugarcane-An "Awesome" Product) http://www.revistarural.com.br/Edicoes/2013/Artigos/rev179_cana.html

[9] Santos, F.A., Queiróz, J.H., Colodette, J.L., Fernandes, S.A., Guimarães, V.M. and Rezende, S.T. (2012) Potencial da palha de cana-de-açúcar para produção de etanol. (Potential of Sugarcane Straw in Ethanol Production) Química Nova, 35, 1004-1010. https://doi.org/10.1590/S0100-40422012000500025 
[10] Tappi. (1988). Tappi Test Methods. Tappi Press, Atlanta.

[11] Associação Brasileira de Normas Técnicas (1986) NBR 8112: Charcoal-Immediate Chemical Analysis-Experiment Method. ABNT, Rio de Janeiro.

[12] Thompson, M. (2008) CHNS Elemental Analysers. AMC Technical Briefs. The Royal Society of Chemistry.

[13] Fangueiro, R. and Rana, S. (2016) Natural Fibres: Advances in Science and Technology towards Industrial Applications. Springer, New York City.

[14] Souza, A.F.R.C. (2013) Study of Bio-Oil Production Feasibility through Fast Pyrolisis Process of Sugarcane Bagasse. Final Project, Universidade de Brasília, Gama.

[15] Seye, O., Cortez, L.A.B. and Gómez, E.O. (2003) Kinetic Study of Biomass through Thermogravimetric Results. Encontro de Energia no Meio Rural, No. 3.

[16] Ferreira, R.A.R. (2012) Contribution to Kinetic Study and Energy Balance of Autothermal Pyrolysis of Sugarcane Straw through Thermogravimetric Analysis and Calorimetry. M.S. Thesis, Universidade Federal de Uberlândia, Uberlândia.

[17] Vieira, A.C. (2012) Characterization of Biomass from Agricultural Waste for Power Generation. M.S. Thesis, Universidade Estadual do Oeste do Paraná, Cascavel.

[18] Reis, A.A., Protásio, T.P., Melo, I.C.N.A., Trugilho, P.F. and Carneiro, A.C.O. (2012) Wood Composition and Charcoal of Eucalyptus urophylla in Different Planting Locations. Revista Florestal Brasileira, 32, 277-290. https://doi.org/10.4336/2012.pfb.32.71.277

[19] Carvalho, D.M. (2012) Phsical-Chemical Characterization and Ethanol/Soda Pulping of Sugarcane Bagasse and Straw. M.S. Thesis, Universidade Federal de Viçosa, Viçosa.

[20] Almeida, M.B.B. (2008) Bio-Oil from Sugar Cane Straw Fast Pyrolysis, Thermal and Catalytic, and Its Co-Processing with Gasoil in Catalytic Cracking. M.S. Thesis, Universidade Federal do Rio de Janeiro, Rio de Janeiro.

[21] Basu, P. (2006) Combustion and Gasification in Fluidized Beds. CRC Press, Boca Raton. https://doi.org/10.1201/9781420005158

[22] Santos, F.A. (2013) Evaluation of Hydrothermal Pretreatment of Sugar Cane Straw Aiming Second Generation Ethanol Production. PhD Thesis, Universidade Federal de Viçosa, Viçosa.

[23] Silva, M.B. and Morais, A.S. (2008) Energetic Evaluation of Sugarcane Bagasse in Different Moisture Contents and Compactation States. Proceedings of 28 th Encontro Nacional de Engenharia de Produção, Rio de Janeiro, 13-16 October 2008, $1-9$.

[24] Oliveira, S.F.A. (2014) Energetic Evaluation of Sugarcane Bagasse Biomass in Different Sucroenergetic Industries. M.S. Thesis, Instituto Tecnológico de Aeronáutica, São José dos Campos.

[25] Quirino, W.F. (2005) Calorific Value of Wood and Lignocellulosic Materials. Revista da Madeira, 89, 100-106.

[26] Lira, R.C., Nascimento, M.S., Silva, M.J. and Rocha, G.J.M. (2013) Pretreatment of Sugarcane Bagasse and Straw in a Semi-Pilot Reactor and Evaluation of Pretreated Biomass Enzymatic Hydrolysis. Proceedings of I CONICBIO/II CONABIO/VI SIMCBIO, Recife, 11-14 November 2013, 1-8.

[27] Rabelo, S.C. (2010) Evaluation and Optimization of Pretreatment and Enzymatic Hydrolysis of Sugarcane Bagasse for the Production of Second Generation Ethanol. PhD Thesis, Universidade Estadual de Campinas, Campinas. 
[28] Pitarelo, A.P. (2007) Evaluation of the Susceptibility of Sugarcane Bagasse and Straw Bioconversion by Steam Pretreatment and Enzymatic Hydrolysis. M.S. Thesis, Universidade Federal do Paraná, Curitiba.

[29] Sindhu, R., Gnansounou, E., Binod, P. and Pandey, A. (2016) Bioconversion of Sugarcane Crop Residue for Value Added Products-An Overview. Renewable Energy, 98, 203-215. https://doi.org/10.1016/j.renene.2016.02.057

[30] Machado, G., Leon, S., Santos, F., Lourega, R., Dullius, J., Mollmann, M.E. and Eichler, P. (2016) Literature Review on Furfural Production from Lignocellulosic Biomass. Natural Resources, 7, 115-129. https://doi.org/10.4236/nr.2016.73012

[31] Sousa-Aguiar, E.F., Appel, L.G., Zonetti, P.C., Fraga, A.C., Bicudo, A.A. and Fonseca, I. (2014) Some Important Catalytic Challenges in the Bioethanol Integrated Biorefinery. Catalysis Today, 234, 13-23.

https://doi.org/10.1016/j.cattod.2014.02.016

[32] Okamoto, K., Nitta, Y., Maekawa, N. and Yanase, H. (2011) Direct Ethanol Production from Starch, Wheat Bran and Rice Straw by the White Rot Fungus Trametes hirsuta. Enzyme and Microbial Technology, 48, 273-277. https://doi.org/10.1016/j.enzmictec.2010.12.001

[33] Amiri, H., Karimi, K. and Zilouei, H. (2014) Organosolv Pretreatment of Rice Straw for Efficient Acetone, Butanol, and Ethanol Production. Bioresource Technology, 152, 450-456. https://doi.org/10.1016/j.biortech.2013.11.038

[34] Órfão, J.J.M. and Figueiredo, J.L. (2001) A Simplified Method for Determination of Lignocellulosic Materials Pyrolysis Kinetics from Isothermal Thermogravimetric Experiments. Thermochimica Acta, 380, 67-80. https://doi.org/10.1016/S0040-6031(01)00634-7

[35] Alvarez, V. and Vázquez, A. (2004) Thermal Degradation of Cellulose Derivatives/Starch Blends and Sisal Fibre Biocomposites. Polymer Degradation and Stability, 84, 13-21. https://doi.org/10.1016/j.polymdegradstab.2003.09.003

[36] Pereira, B.L.C., Carneiro, A.C.O., Carvalho, A.M.M., Trugilho, P.F., Melo, I.C.N.A. and Oliveira, A.C. (2013) Study of Thermal Degradation of Eucalyptus Wood by Thermogravimetry and Calorimetry. Revista Árvore, 37, 567-576.

https://doi.org/10.1590/S0100-67622013000300020 